Terbit online pada laman web jurnal: http://jurnal.iaii.or.id

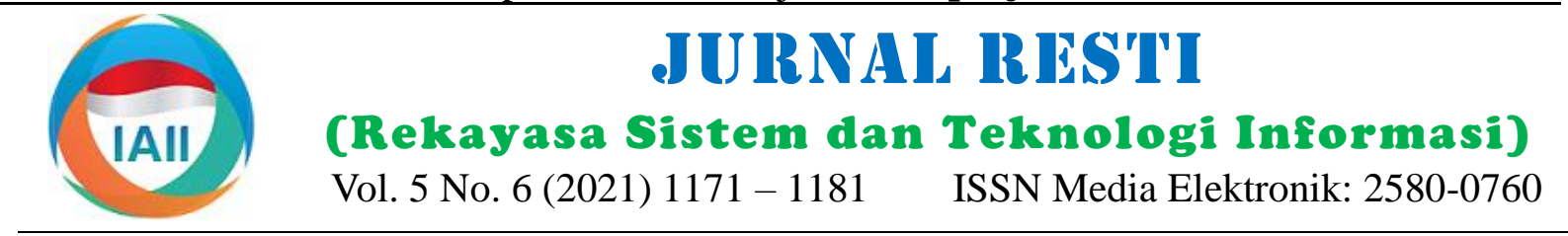

\title{
Pengembangan Embedded Device Berbasis PLC untuk Simulator Rejection System dengan Penambahan Human Machine Interface
}

\author{
Riyandar ${ }^{1}$, Muhamad Wildan ${ }^{2}$, Arief Goeritno ${ }^{3 *}$, Joki $\operatorname{Irawan}^{3}$ \\ ${ }^{1}$ CV Rochi Herba Care, Jalan Nilem Blok DD5 No.1-2, Padasuka, Ciomas, Bogor 16610 \\ ${ }^{2}$ PT Cisarua Mountain Dairy, Jalan Raya Sentul No.101 RT05/RW05 Babakan Rawahaur, Sentul, Babakan Madang, Bogor \\ 16810 \\ ${ }^{3}$ Program Studi Teknik Elektro, Fakultas Teknik dan Sains, Universitas Ibn Khaldun Bogor, Jalan Sholeh Iskandar km.2, \\ Kedungbadak, Tanah Sareal, Kota Bogor 16164 \\ ${ }^{1}$ riyandarriyand@gmail.com, ${ }^{2}$ bheenwildan07@gmail.com, ${ }^{3}$ arief.goeritno@ uika-bogor.ac.id*, ${ }^{3}$ oqirawan05@gmail.com
}

\begin{abstract}
Changes to the simulator rejection system from the previous research were carried out by replacing all sensors, drive motors, PLC systems, and adding HMI systems. The objectives in this research, namely (i) changing and developing a rejection system simulator, creating a ladder-based program structure and configuring HMI systems and (ii) measuring the performance of the simulators. Rejection system simulator is fabricated and reassembled, ladder-based syntax into PLCs and HMI is also configured, and observing the performance is done through the HMI layer. The results of programming is carried out through (i) providing software for PLCs, (ii) programming the PLC system, (iii) compiling and uploading programs from PC to PLC, (iv) configuring PLC and HMI via ethernet, and (v) compiling and uploading the program structure from PC to HMI. The performance for observing the condition of the bottle cap through the HMI is observed when (i) synchronization between the simulator system and the HMI-assisted PLC control, (ii) the reading of the sensors installed on the simulator, and (iii) the rotation process of the rejector arm. Overall, the rejection system simulator with a PLC-based assisted by HMI can be used as a process simulation against the implementation of the rejection system.
\end{abstract}

Keywords: analogy of conveyor, HMI, PLC, simulator of rejection system.

\begin{abstract}
Abstrak
Pengubahan terhadap simulator rejection system hasil penelitian sebelumnya, dilakukan melalui penggantian seluruh sensor, motor penggerak, sistem PLC, dan penambahan sistem HMI. Sasaran pada penelitian ini, yaitu (i) pembuatan struktur program berbasis ladder diagram dan pengkonfigurasian sistem HMI dan (ii) pengukuran kinerja simulator. Simulator rejection system pada miniature mesin konveyor, dipabrikasi dan dirakit kembali, sintaks program ditanamkan ke PLC dan HMI dikonfigurasi, dan pengamatan terhadap kinerja simulator rejection system untuk pengamatan kondisi tutup botol dilakukan melalui layer pada $H M I$. Hasil pemrograman dilakukan melalui (i) penyediaan software untuk $P L C$, (ii) pemrograman sistem $P L C$, (iii) proses compiling dan uploading struktur program dari $P C$ ke $P L C$, (iv) konfigurasi $P L C$ dan $H M I$ via ethernet, dan (v) proses compiling dan uploading struktur program dari $P C$ ke $H M I$. Kinerja untuk pengamatan kondisi terhadap tutup botol melalui $H M I$, diamati saat (i) sinkronisasi antara sistem simulator dan kontrol PLC berbantuan $H M I$, (ii) pembacaan oleh sensor-sensor terpasang pada simulator, dan (iii) proses putaran lengan rejector. Secara keseluruhan, simulator rejection system berbasis $P L C$ dan berbantuan $H M I$ dapat digunakan untuk simulasi proses terhadap implementasi sistem rejection.
\end{abstract}

Kata kunci: analogi konveyor, HMI, PLC, simulator rejection system.

\section{Pendahuluan}

Simulator rejection system terkendali embedded device berbasis Programmable Logic Controller (PLC) pada miniatur mesin konveyor hasil penelitian sebelumnya [1], menjadi pedoman untuk dilakukan fungsionalisasi kembali terhadap miniatur mesin konveyor disertai penggantian dan penambahan peranti elektronika. Penggantian sistem PLC [2,3] dan motor listrik sebagai penggerak miniature konveyor, sedangkan bentuk fisis dan fungsi miniatur konveyor tidak berubah. Jumlah sensor terpasang bertambah, ditambahkan sistem

Diterima Redaksi: 19-11-2021 | Selesai Revisi: 25-12-2021 | Diterbitkan Online: 30-12-2021 
Human Machine Interface (HMI) Schneider GXU3512 sensor ke \#5 yang diletakkan pada sisi akhir konveyor. [4], dan pemasangan boks penampungan botol dengan Diagram skematis hasil fungsionalisasi kembali kondisi tutup botol terpasang baik. Boks penampungan terhadap simulator rejection system pada penelitian ini, dilengkapi dengan sensor proximity tipe induktif sebagai seperti ditunjukkan pada Gambar 1 .

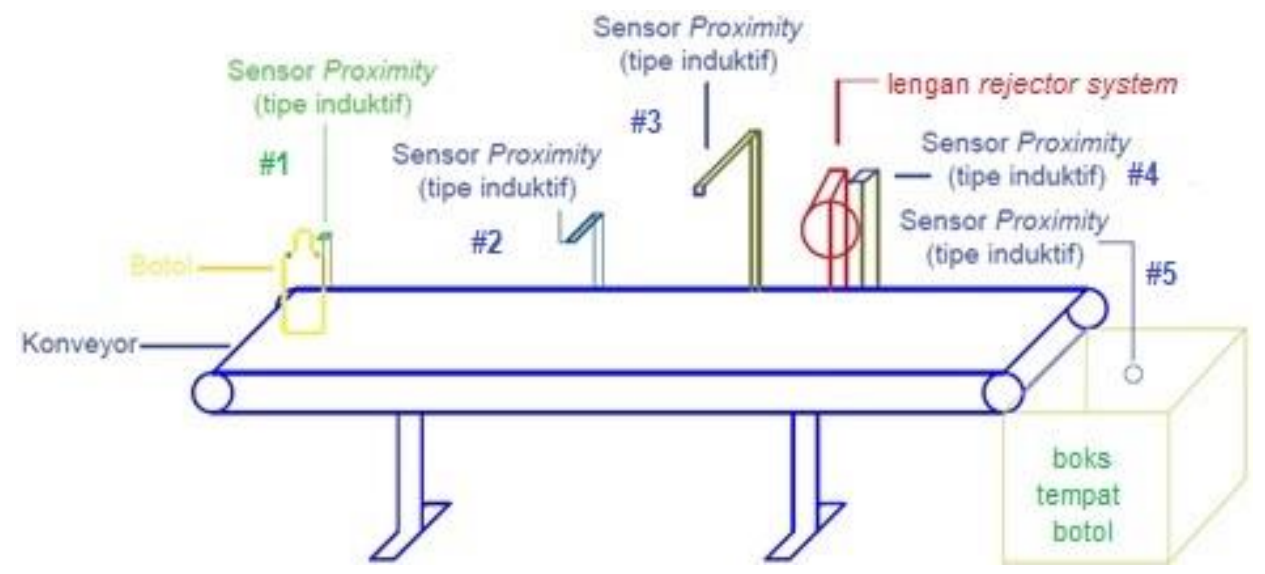

Gambar 1. Diagram skematis hasil fungsionalisasi kembali terhadap simulator rejection system pada penelitian ini

Berdasarkan Gambar 1 dapat dijelaskan mekanisme Human Machine Interface merupakan sistem pengoperasian simulator rejection system. Urutan penghubung antara manusia dan mesin yang dapat pertama, setiap botol yang telah diisi dan diberi tutup berupa pengendali dan visualisasi status dengan secara otomatis, kemudian dideteksi oleh sensor pengoperasian manual atau melalui visualisasi proximity tipe induktif ke \#1 [5], sehingga mesin computer, sehingga pembacaan data pada sistem $H M I$ konveyor beroperasi. Setelah tutup botol terdeteksi terkirim melalui jalur (port) masukan/keluaran sensor proximity ke \#2, maka pemisah botol beroperasi (input/output, I/O) pada PLC, secara online dan realuntuk pemisahan botol dengan kondisi tutup botol tidak sesuai standar, sedangkan botol dengan kondisi tutup sesuai standar digerakkan sampai masuk ke boks tempat botol "rejected". Untuk kondisi dimana keadaan boks terdeteksi penuh oleh sensor proximity ke \#5, maka konveyor tidak beroperasi. Setelah pengambilan botol dari boks dan keadaan boks terdeteksi "kosong" oleh sensor proximity ke \#5, maka konveyor beroperasi kembali secara otomatis. Mekanisme pendeteksian terhadap kondisi tutup tidak sesuai standar dideteksi oleh sensor proximity ke \#3 dan diarahkan oleh motor wiper ke area tempat rejecton setelah hasil deteksi sensor proximity ke \#4.

Beberapa penelitian berkaitan dengan adopsi terhadap acuan Internasional yang berkaitan dengan Automated Visual Inspection Systems for Indutrial Applications [6] berupa rancangan sistem automated bottle cap inspection using machine vision system berbasis chip mikrokontroler dari keluarga AVR-ATmega telah terdiseminasikan [7]. Hasil penelitian lain berupa bottle cap inspection based on machine vision berbantuan metode fuzzy [8] juga telah telah terdiseminasikan. Automated Visual Inspection Systems (AVIS) berkaitan dengan sistem pengontrolan berbasis penggunaan sensor vision kamera untuk pendeteksian objek, motor $d c$ untuk penggerak belt conveyor dan motor stepper untuk rejector systemr [6-8], termasuk perpaduan $P L C$ dan $H M I$ untuk pemantauan objek pada sistem konveyor [9]. time. Fungsi-fungsi HMI, meliputi (i) pemantauan keadaan pada plant, (ii) pengaturan nilai parameter pada plant, (iii) pengambilan tindakan sesuai keadaan yang terjadi, (iv) penampilan tanda peringatan dengan alarm untuk kondisi tidak normal, dan (v) penampilan pola data kejadian pada plant secara real-time dan/atau trending history.

Penelitian lain terkait prototipe rejection system untuk selektivitas terhadap tutup botol kemasan minuman telah dipabrikasi [1] melalui sejumlah tahapan, yaitu (i) pembuatan miniatur mesin konveyor, (ii) penempatan sejumlah sensor dan motor stepper sebagai penggerak lengan rejector, (iii) pengawatan pada sistem Programmable Logic Controller (PLC), dan (iv) pengintegrasian sistem. Sistem $P L C$ secara umum [10] maupun secara khusus untuk sistem pengontrolan sebuah sistem tertanam $[11,12,1]$ termasuk juga untuk keperluan pengoperasian rejection system [1], merupakan sistem dengan kebutuhan program (aplikasi) tertanam berbasis ladder diagram. Prototipe (purwarupa) rejection system terpabrikasi berbentuk dan difungsikan sebagai sebuah simulator peragaan penerapan konsepsi instrumentasi dan otomasi untuk fenomena di sistem rejection [1].

Sistem PLC bermakna sebagai pengontrol logika terprogram [10] dengan keberadaan komputer solidstate industri untuk pemantauan masukan-keluaran (input-output) dan pembuatan keputusan berbasis logika

DOI: https://doi.org/10.29207/resti.v5i6.3641

Lisensi: Creative Commons Attribution 4.0 International (CC BY 4.0) 
dalam suatu proses otomatisasi [11-18]. Keberadaan sebelumnya, terutama pada penggantian sistem $P L C$, sebuah PLC sebagai pusat pengontrol [11, 12], termasuk sebelumnya bermerek Omron [2] diganti dengan pemanfaatan komputer personal (personal computer, merek Schneider TM221CE40R [3]. Penggantian motor $P C)$ [19], maupun pemasangan single chip listrik sebagai penggerak miniature konveyor dari tipe mikrokontroler (microcontroller, $u C$ ) untuk servo ke wiper. Penambahan jumlah sensor jenis keterwujudan sebuah motherboard [20-25] atau proximity menjadi lima buah, kesemuanya dengan tipe penggunaan modul Arduino UNO R3 [26-33] atau induktif dengan merek Panasonic tipe LJ12A3-4-Z NPN Arduino MEGA2560 R3 [30, 34-36] sebagai pengendali yang dipadukan dengan sensor-sensor di sisi masukan untuk pengontrolan sisi keluaran, telah menjadi keniscayaan dewasa ini. Ketersediaan PLC merek Omron tipe CP1E [2] atau PLC secara umum terpasang pada sistem otomasi di industri [13,15-18] telah digunakan untuk sistem otomasi pengemasan susu dalam botol terhadap purwarupa filling bottle and capping machine [37]. Sistem otomasi tersebut merupakan salah satu bentuk implementasi otomatisasi permesinan di bidang industri [13,15-18]. Implementasi PLC pada sistem, difungsikan sebagai pengontrol proses $6 \mathrm{~V}-36 \mathrm{~V}$. Jumlah sensor proximity sebelumnya sebanyak empat buah, tiga buah tipe induktif dan satu buah tipe optik. Untuk pencapaian pengembangan sistem, ditambahkan HMI Schneider GXU3512 [4] dan pemasangan boks penampungan untuk tiga buah botol yang dilengkapi dengan sensor proximity \#5). Boks penampungan untuk tempat botol dengan kondisi tutup botol terpasang baik yang diletakkan pada bagian akhir miniatur konveyor. Sejumlah subsistem untuk dukungan terhadap pengembangan sistem pengontrol pada miniatur mesin konveyor, yaitu relai elektromekanis, push button, kabel penghubung, catu daya mode pensaklaran (switched-mode power supply, SMPS) 24 pengisian cairan ke dalam botol berbantuan mesin $\mathrm{V} d c$ dan $12 \mathrm{~V} d c$, motor $d c$ sebagai penggerak miniatur konveyor dengan penggerak mekanis untuk proses belt comveyor, dan motor wiper tipe universal sebagai penggerakan botol. Penggerakan mesin konveyor penggerak lengan rejector system. Pengoperasian dilakukan dengan bantuan motor listrik jenis direct simulator rejection system berbasis PLC dan HMI untuk current $(d c)$ [11,12] yang didukung oleh keberadaan pemantauan terhadap kekurangsempurnaan saat Human Machine Interface (HMI).

pemasangan tutup botol. Pemantauan terhadap pemasangan tutup botol dilakukan setelah proses Berpedoman kepada mekanisme pengoperasian dan pengisian cairan ke dalam botol selesai dilakukan. pengacuan terhadap sejumlah hasil penelitian Diagram skematik untuk fungsionalisasi simulator sebelumnya, maka dibuat penelitian tentang rejection rejection system berbasis PLC yang dilengkapi dengan system. Pengembangan dari sistem terpabrikasi HMI, seperti ditunjukkan pada Gambar 2.

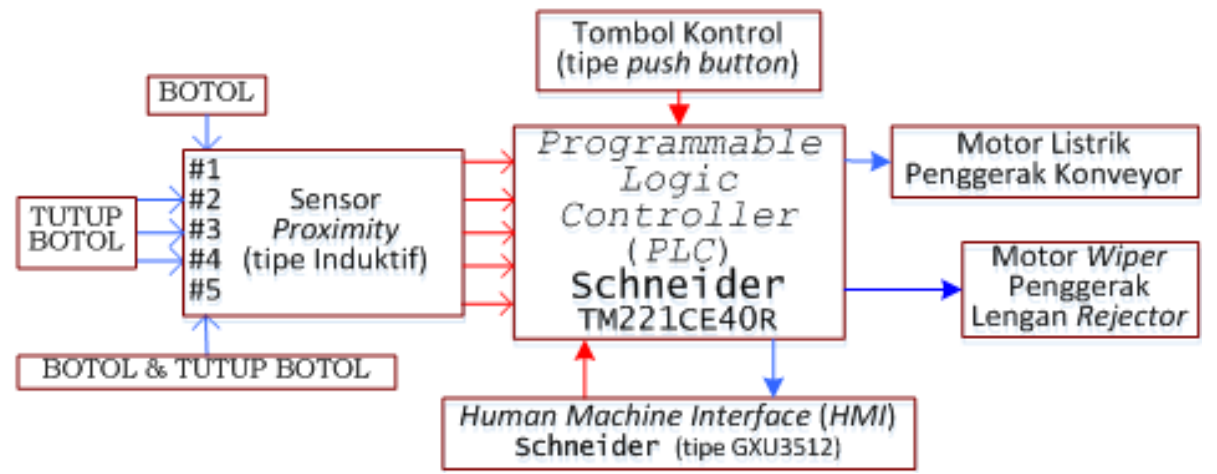

Gambar 2. Diagram skematik untuk fungsionalisasi simulator rejection system berbasis $P L C$ yang dilengkapi dengan $H M I$

Berdasarkan Gambar 2, maka ditetapkan dapat botol dengan tutup "kondisi baik" dimasukkan pada dijelaskan, bahwa terdapat dua sasaran penelitian (1) boks dan proses pengangkatan atau penurunan lengan memfungsikan kembali miniatur konveyor dan rejector berbantuan sistem motor wiper. memrogram system PLC dan HMI berbasis ladder diagram, dilakukan melalui pembuatan driver baru, 2. Metode Penelitian

konfigurasi $P L C$ dan $H M I$ dengan masukan alamat $I P$, dan penyimpanan data ke dalam memori di $H M I$ dan (2) mengukur kinerja system, melalui beberapa pengamatan, yaitu (i) saat sinkronisasi antara prototipe dan kontrol PLC berbantuan $H M I$, (ii) saat pembacaan sensor-sensor terpasang pada prototipe, dan (iii) saat
Untuk pencapaian sasaran penelitian, maka ditetapkan metode penelitian dengan dukungan bahan-bahan penelitian. Sejumlah perangkat keras untuk pengubahan dan pengembangan sistem pengontrol pada miniatur mesin konveyor, meliputi PLC Schneider TM221CE40R [3], HMI Schneider GXU3512 [4], 
sensor proximity tipe induktif merek Panasonic tipe $\mathrm{V} d c$, motor $d c$ sebagai penggerak miniatur belt LJ12A3-4-Z NPN 6V-36V, relai elektromekanik, push comveyor, dan motor wiper universal sebagai penggerak button, kabel penghubung, catu daya mode pensaklaran lengan rejector system. Diagram alir metode penelitian, (switched-mode power supply, SMPS) $24 \mathrm{Vdc}$ dan 12 seperti ditunjukkan pada Gambar 3.
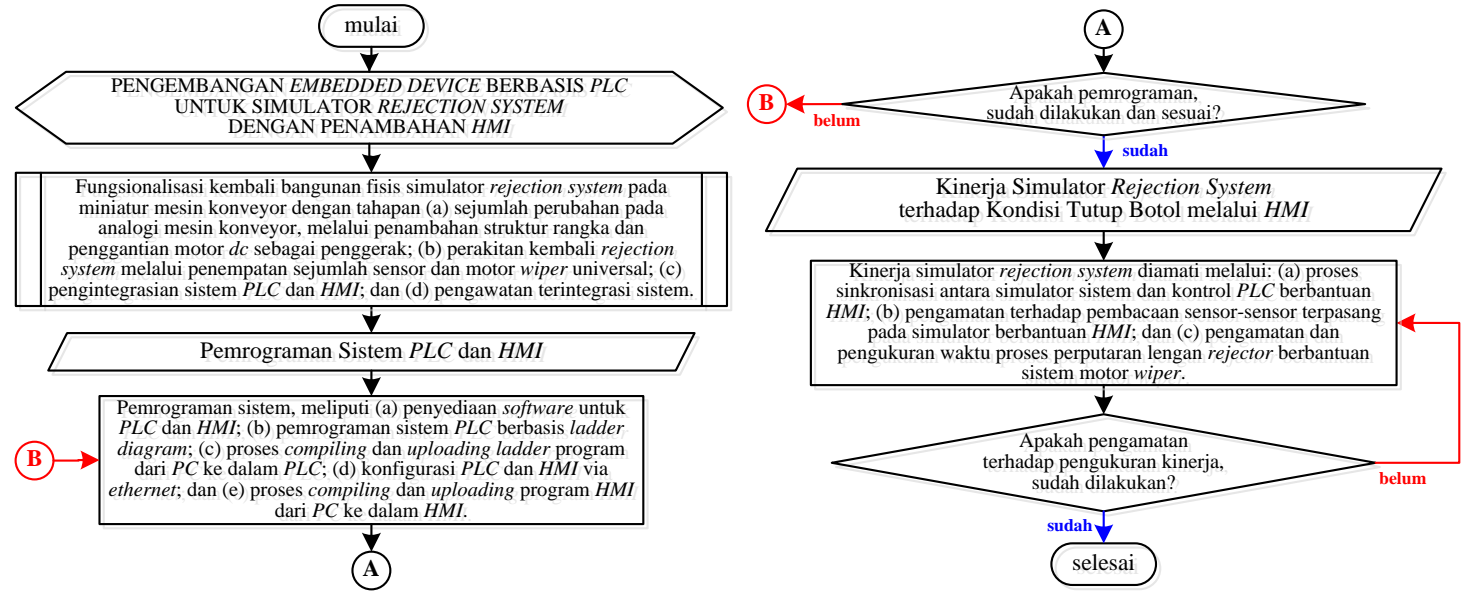

Gambar 3. Diagram alir metode penelitian

Berdasarkan Gambar 3 dapat dijelaskan, bahwa pada pengintegrasian seluruh komponen, dan (c) pengawatan metode penelitian ini terkait dengan pencapaian dua terintegrasi terhadap sistem sensor dan penggerak sasaran penelitian. Fungsionalisasi kembali miniatur aktuator, juga $P L C$ dan $H M I$, maka diperoleh sistem konveyor dan pemrogramanan sistem $P L C$ dan HMI pengontrol simulator rejection system berbasis $P L C$ dan berbasis ladder diagram dilakukan melalui (i) HMI berbantuan miniatur mesin konveyor. Sejumlah penyediaan software untuk PLC dan HMI, (ii) komponen untuk pengembangan simulator rejection pemrograman sistem $P L C$ berbasis ladder diagram, (iii) system untuk pengamatan terhadap tutup botol terdiri proses compiling dan uploading program dari $P C$ ke atas (i) motor $d c$ sebagai penggerak belt, (ii) motor wiper dalam $P L C$, (iv) konfigurasi $P L C$ dan HMI via ethernet, sebagai penggerak lengan rejector botol, dan (iii) dan (v) proses compiling dan uploading program dari $P C$ sejumlah sensor. Sensor-sensor proximity terpasang ke dalam HMI. Kinerja simulator rejection system untuk sebagai alat deteksi (i) pengoperasioan konveyor ketika pengamatan kondisi tutup botol melalui HMI diamati pendeteksian keberadaan botol pada konveyor, (ii) saat (i) sinkronisasi antara prototipe sistem dan kontrol perbedaan kondisi tutup botol, (iii) penghitung tutup PLC berbantuan HMI, (ii) pembacaan sensor-sensor botol rejected dan bagus, dan (iv) penonaktifan terpasang pada prototipe, dan (iii) proses perputaran konveyor ketika pendeteksian terhadap kondisi boks lengan rejector berbantuan sistem motor wiper.

\section{Hasil dan Pembahasan}

Penyelesaian terhadap beberapa tahapan, yaitu (a) fungsionalisasi kembali bangunan fisis simulator rejection system pada miniatur mesin konveyor, (b) sudah terisi penuh botol dengan tutup sesuai standar. Sensor-sensor terpasang pada rangka miniatur mesin konveyor, berupa sensor proximity tipe induktif. Pemasangan sensor-sensor pada miniatur mesin konveyor untuk simulator rejection system yang telah dikembangkan, seperti ditunjukkan pada Gambar 4.

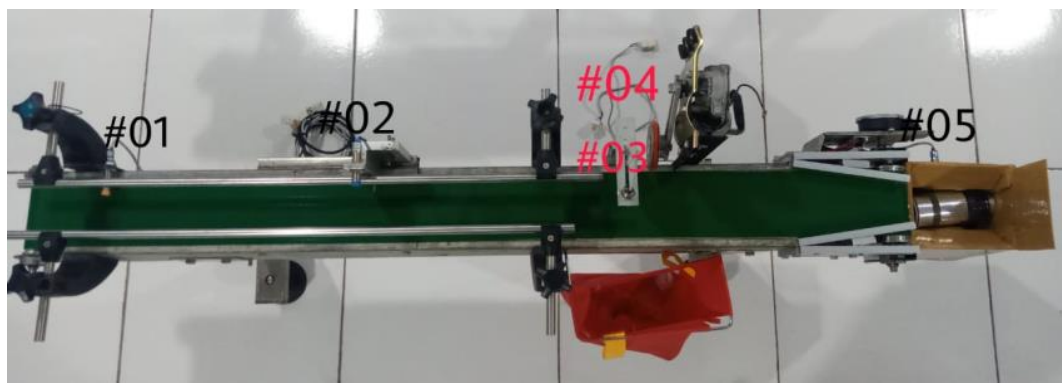

Keterangan pada gambar: \#01: Proximity Sensor\#1 untuk pengoperasian mesin konveyor, \#02: Proximity Sensor \#2 penghitung jumlah botol terdeteksi, \#03: Proximity Sensor \#3 penghitung jumlah botol rejected, \#04: Proximity Sensor \#4 lengan rejector ((posisi lengan rejector setelah bergerak dalam penjatuhan botol), dan \#05: Proximity Sensor \#5 pendeteksian boks kondisi penuh.

Gambar 4. Pemasangan sensor-sensor pada miniatur mesin konveyor untuk simulator rejection system yang telah dikembangkan

DOI: https://doi.org/10.29207/resti.v5i6.3641

Lisensi: Creative Commons Attribution 4.0 International (CC BY 4.0) 
Riyandar, Muhamad Wildan, Arief Goeritno, Joki Irawan Jurnal RESTI (Rekayasa Sistem dan Teknologi Informasi) Vol. 5 No. 6 (2021) 1171 - 1181

Berpedoman kepada Gambar 4, maka dilakukan penetapan alamat pada jalur (port) masukan dan keluaran di sistem PLC Schneider TM221CE40R. Pengalamatan pada jalur, seperti ditunjukkan pada Tabel 1.

\begin{tabular}{|c|c|c|c|}
\hline \multicolumn{2}{|c|}{ Jalur Masukan (input port) } & \multicolumn{2}{|c|}{$\begin{array}{c}\text { Jalur Keluaran } \\
\text { (output port })\end{array}$} \\
\hline $\begin{array}{l}\text { Alamat } \\
P L C\end{array}$ & Kegunaan & $\begin{array}{c}\text { Alamat } \\
P L C\end{array}$ & Kegunaan \\
\hline$\% \mathrm{I} 0.9$ & $\begin{array}{l}\text { Sensor untuk pembacaan } \\
\text { "terdapat botol" }\end{array}$ & & \\
\hline$\% \mathrm{I} 0.10$ & $\begin{array}{l}P B \text { untuk motor penggerakan } \\
\text { "lengan rejector" }\end{array}$ & & \\
\hline$\% \mathrm{I} 0.11$ & $\begin{array}{c}P B \text { untuk operasi mesin } \\
\text { konveyor }\end{array}$ & & \\
\hline$\% \mathrm{I} 0.12$ & $\begin{array}{l}\text { Sensor untuk kondisi boks } \\
\text { "penuh dengan botol" }\end{array}$ & & \\
\hline Keterans & n: $P B=$ push button & & \\
\hline
\end{tabular}

Tabel 1. Pengalamatan pada jalur masukan dan keluaran

\begin{tabular}{|c|c|c|c|}
\hline \multicolumn{2}{|c|}{ Jalur Masukan (input port) } & \multicolumn{2}{|c|}{$\begin{array}{l}\text { Jalur Keluaran } \\
\text { (output port) }\end{array}$} \\
\hline $\begin{array}{c}\text { Alamat } \\
P L C\end{array}$ & Kegunaan & $\begin{array}{l}\text { Alamat } \\
P L C\end{array}$ & Kegunaan \\
\hline$\% \mathrm{I} 0.0$ & $P B$ untuk Emergency Stop & $\% \mathrm{Q} 0.0$ & R2 \\
\hline$\% \mathrm{I} 0.1$ & Auto Selector Switch & $\% \mathrm{Q} 0.4$ & lampu \\
\hline$\% \mathrm{I} 0.2$ & Manual Selector Switch & $\% \mathrm{Q} 0.5$ & R1 \\
\hline$\% \mathrm{I} 0.3$ & $P B$ untuk "STOP” & & \\
\hline$\% \mathrm{I} 0.4$ & $P B$ untuk "START" & & \\
\hline$\% \mathrm{I} 0.5$ & $\begin{array}{l}\text { Sensor untuk operasi } \\
\text { "lengan rejector" }\end{array}$ & & \\
\hline$\% \mathrm{I} 0.6$ & $\begin{array}{l}\text { Sensor untuk pengamatan } \\
\text { kondisi "tutup botol OK" }\end{array}$ & & \\
\hline$\% \mathrm{I} 0.8$ & $\begin{array}{l}\text { Sensor untuk pengamatan } \\
\text { "tutup botol rejected" }\end{array}$ & & \\
\hline
\end{tabular}

Berdasarkan Tabel 1 dapat dijelaskan, bahwa pengalamatan pada input port dan output port di PLC mutlak ditentukan dan ditetapkan untuk kemudahan dalam proses pengawatan dan pemrograman. Diagram pengawatan terintegrasi untuk keterhubungan port masukan dan keluaran sistem PLC, seperti ditunjukkan pada Gambar 5.

\#bagian (2)

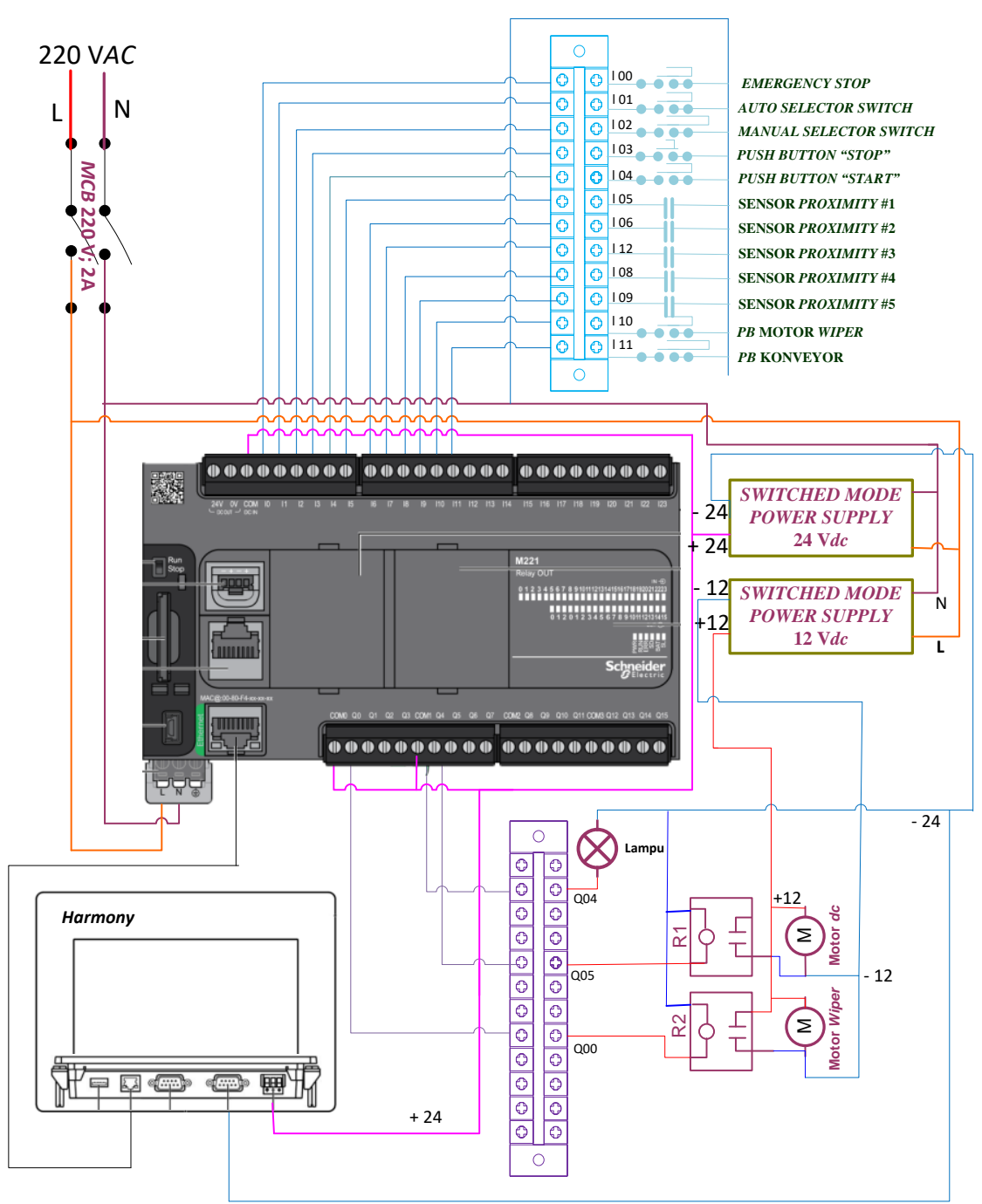

Gambar 5. Diagram pengawatan terintegrasi untuk keterhubungan port masukan dan keluaran sistem $P L C$

DOI: https://doi.org/10.29207/resti.v5i6.3641

Lisensi: Creative Commons Attribution 4.0 International (CC BY 4.0) 


\subsection{Pemrograman Sistem PLC dan HMI}

Sebelum pelaksanaan pemrograman terhadap sistem $P L C$ dan $H M I$, diawali dengan penyediaan software dan pemasangan pada $P C$, dilanjutkan dengan penetapan alamat memori pada sistem PLC Schneider TM221CE40R. Aplikasi untuk pembuatan ladder diagram, yaitu "EcoStruxure Machine Expert-Basic", melalui (i) pembukaan link pada Google Drive yang telah diterima, (ii) pemilihan Eco Struxure Machine Expert-Basic, (iii) pengunduhan file, dan (iv) pemasangan (installing) aplikasi (software). Aplikasi "Eco Struxure Machine Expert-Basic" disimpan dalam $P C$. Setelah software berhasil dipasang dan "Eco Struxure Machine Expert-Basic" siap untuk digunakan.

Penyediaan software untuk pemrograman HMI melalui pembukaan link hasil pengunduhan (downloading) dan pemasangan software pada $P C$. Setelah ketersedian software "Vijeo Designer Basic", dilakukan tahapan lanjutan berupa (a) pemrograman sistem $P L C$ berbasis ladder diagram, (b) proses compiling dan uploading struktur program ladder dari $P C$ ke dalam $P L C$, (c) konfigurasi $P L C$ dan $H M I$ via ethernet, dan (d) proses compiling dan uploading struktur program dari $P C$ ke dalam $H M I$.

Pengalamatan memori, seperti ditunjukkan pada Tabel 2.

\begin{tabular}{|c|c|}
\hline $\begin{array}{l}\text { Memori } \\
P L C\end{array}$ & Keterangan \\
\hline$\% \mathrm{M} 0$ & Internal Relay untuk Emergency Stop \\
\hline$\% \mathrm{M} 1$ & Internal Relay untuk Manual Push Button \\
\hline$\% \mathrm{M} 2$ & Internal Relay untuk Auto Push Button \\
\hline$\% \mathrm{M} 3$ & $\begin{array}{l}\text { Internal Relay untuk "STOP" pada Push Button for } \\
\text { AUTO MODE }\end{array}$ \\
\hline$\% \mathrm{M} 4$ & $\begin{array}{l}\text { Internal Relay untuk "START" pada Push Button } \\
\text { for AUTO MODE }\end{array}$ \\
\hline$\%$ M5 & Internal Relay untuk Sensor lengan rejector \\
\hline$\% \mathrm{M} 6$ & $\begin{array}{l}\text { Internal Relay untuk sensor pengamatan terhadap } \\
\text { kondisi "tutup botol OK" }\end{array}$ \\
\hline$\% \mathrm{M} 8$ & $\begin{array}{l}\text { Internal Relay untuk sensor pengamatan terhadap } \\
\text { kondisi "tutup botol NG" }\end{array}$ \\
\hline$\% \mathrm{M} 9$ & $\begin{array}{l}\text { Internal Relay untuk sensor deteksi keberadaan } \\
\text { botol }\end{array}$ \\
\hline$\%$ M10 & $\begin{array}{l}\text { Internal Relay untuk Push Button operasi mesin } \\
\text { konveyor secara "MAN" }\end{array}$ \\
\hline$\% \mathrm{M} 11$ & $\begin{array}{l}\text { Internal Relay untuk Push Button operasi motor } \\
\text { penggerakan "lengan rejector" }\end{array}$ \\
\hline$\% \mathrm{M} 12$ & $\begin{array}{l}\text { Internal Relay untuk deteksi kondisi boks "penuh } \\
\text { dengan botol" }\end{array}$ \\
\hline$\%$ M50 & $\begin{array}{l}\text { Operasi motor penggerakan "lengan rejector" } \\
\text { secara "MAN" }\end{array}$ \\
\hline$\%$ M54 & Lampu (indicator) \\
\hline$\%$ M55 & $\begin{array}{l}\text { Operasi motor penggerak mesin konveyor secara } \\
\text { "MAN" }\end{array}$ \\
\hline$\% \mathrm{M} 60$ & $\begin{array}{l}\text { Operasi motor penggerakan "lengan rejector" } \\
\text { secara "AUTO" }\end{array}$ \\
\hline$\% \mathrm{M} 65$ & $\begin{array}{l}\text { Operasi motor penggerak mesin konveyor secara } \\
\text { "AUTO" }\end{array}$ \\
\hline$\% \mathrm{M} 70$ & Timer untuk tundaan waktu botol rejected \\
\hline$\%$ M71 & $\begin{array}{l}\text { Timer untuk kondisi "STOP" mesin konveyor, } \\
\text { karena ketiadaan botol terdeteksi }\end{array}$ \\
\hline
\end{tabular}

\%M72 Deteksi kondisi boks "penuh dengan botol"

\#) Pemrograman sistem PLC berbasis ladder diagram

Setelah penyediaan dan pemasangan software dan penetapan alamat memori pada sistem $P L C$, maka dapat dilakukan proses pemrograman. Tahapan pada pemrograman PLC dilakukan melalui penentuan algoritma dan penulisan sintaks. Algoritma pemrograman dipilih dan dibuat dalam bentuk diagram alir, sedangkan penyusunan sintaks struktur program berbasis ladder diagram. Algoritma berbentuk diagram alir untuk pengoperasian rejection system berbantuan miniatur mesin konveyor pada pengamatan kondisi tutup botol, seperti ditunjukkan pada Gambar 6 .

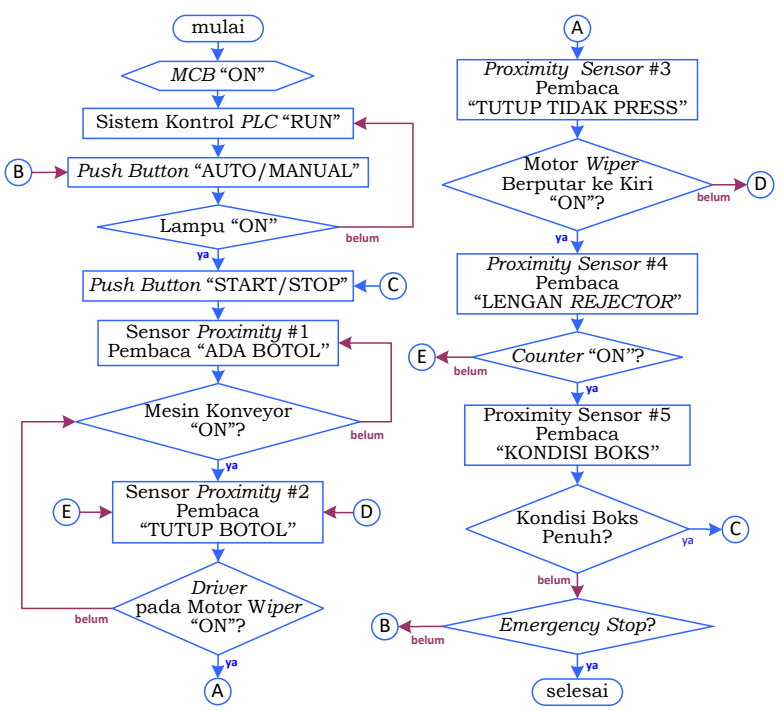

Gambar 6. Algoritma berbentuk diagram alir untuk pengoperasian rejection system berbantuan miniatur mesin konveyor untuk pengamatan kondisi tutup botol

\#) Proses compiling dan uploading struktur program dari $P C$ ke dalam $P L C$ dan $H M I$ dan konfigurasi $P L C$ dan $H M I$ via ethernet

Setelah diperoleh struktur ladder diagram, ditindaklanjuti dengan compiling dan uploading dari $P C$ ke $P L C$ dan HMI berbantuan konektor USB. Proses compiling dan uploading program dari $P C$ ke $P L C$ dilakukan dalam dua tahapan, yaitu login to PLC dan transferring to the machine, sedangkan proses compiling berupa "build all" dan proses uploading program untuk $H M I$ dari $P C$ ke $H M I$ berupa "download all". Konfigurasi PLC dan HMI dilakukan dengan bantuan kabel Ethernet, meliputi (i) penyetelan (setting) IP address dan (ii) setting subnet mask. Subnet mask pada $P L C$ disamakan dengan setting di HMI, agar satu jaringan.

Proses sharing variables antara "EcoStruxure Machine Expert-Basic" dan "Vijeo Designer Basic", meliputi (i) link variables, (ii) pilih file of type SoMachnie Basic Priject files dan file name PROYEK SIMULATOR, (iii)

DOI: https://doi.org/10.29207/resti.v5i6.3641

Lisensi: Creative Commons Attribution 4.0 International (CC BY 4.0) 
add new variable, (iv) update link, dan (v) pilih file kontrol PLC berbantuan HMI, (b) saat pengamatan kemudian update all. Tampilan proses konfigurasi HMI, terhadap pembacaan sensor-sensor terpasang pada seperti ditunjukkan pada Gambar 7.

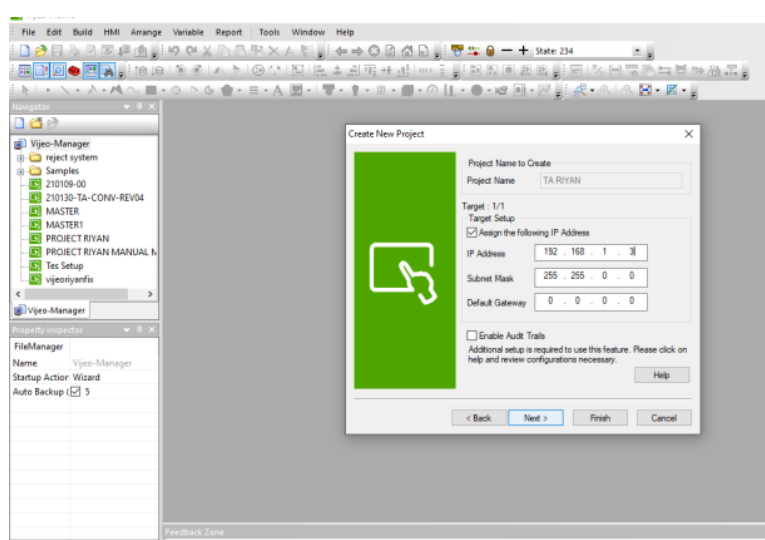

Gambar 7. Tampilan proses konfigurasi $H M I$ simulator sistem berbantuan HMI, dan (c) saat pengamatan dan pengukuran waktu proses putaran lengan rejector berbantuan sistem motor wiper.

@ Sinkronisasi antara simulator sistem dan kontrol PLC berbantuan $H M I$

Pilihan operasi dalam dua mode, yaitu mode manual dan auto. Mode manual digunakan untuk kemudahan operator saat perawatan, pengecekan, dan penanganan saat terjadi error step. Saat mode manual diaktifkan, pengoperasian penggerak konveyor dilkukan secara manual tanpa harus dengan perlibatan sensor pembaca kondisi keberadaan botol, tanpa perlibatan tutup botol "not OK" ataupun tidak terdapat tutup botol pada belt conveyor. Saat pilihan mode auto, maka pengoperasian rejection system untuk pengamatan kondisi tutup botol

Berdasarkan Gambar 7 ditunjukkan, bahwa angka pada miniatur mesin konveyor dioperasikan melalui terakhir pada IP address PLC dan HMI dibedakan, sistem PLC dan berbantuan HMI. Layar pada HMI karena pembeda alamat $P L C$ dan $H M I$. menjadi panel kontrol pengoperasian simulator rejector system untuk pengamatan kondisi tutup botol pada

3.2. Kinerja Prototipe Rejection System Tutup Botol miniatur mesin konveyor. Masukan dari panel melalui HMI

Pengukuran kinerja dilakukan terhadap tiga kondisi, yaitu (a) saat sinkronisasi antara simulator sistem dan pengoperasian dan masukan dari sensor, diproses dalam program $P L C$, sehingga dihasilkan keluaran hasil pengontrolan yang sesuai dan tepat sasaran. Tampilan pada layar HMI, seperti ditunjukkan pada Gambar 8.

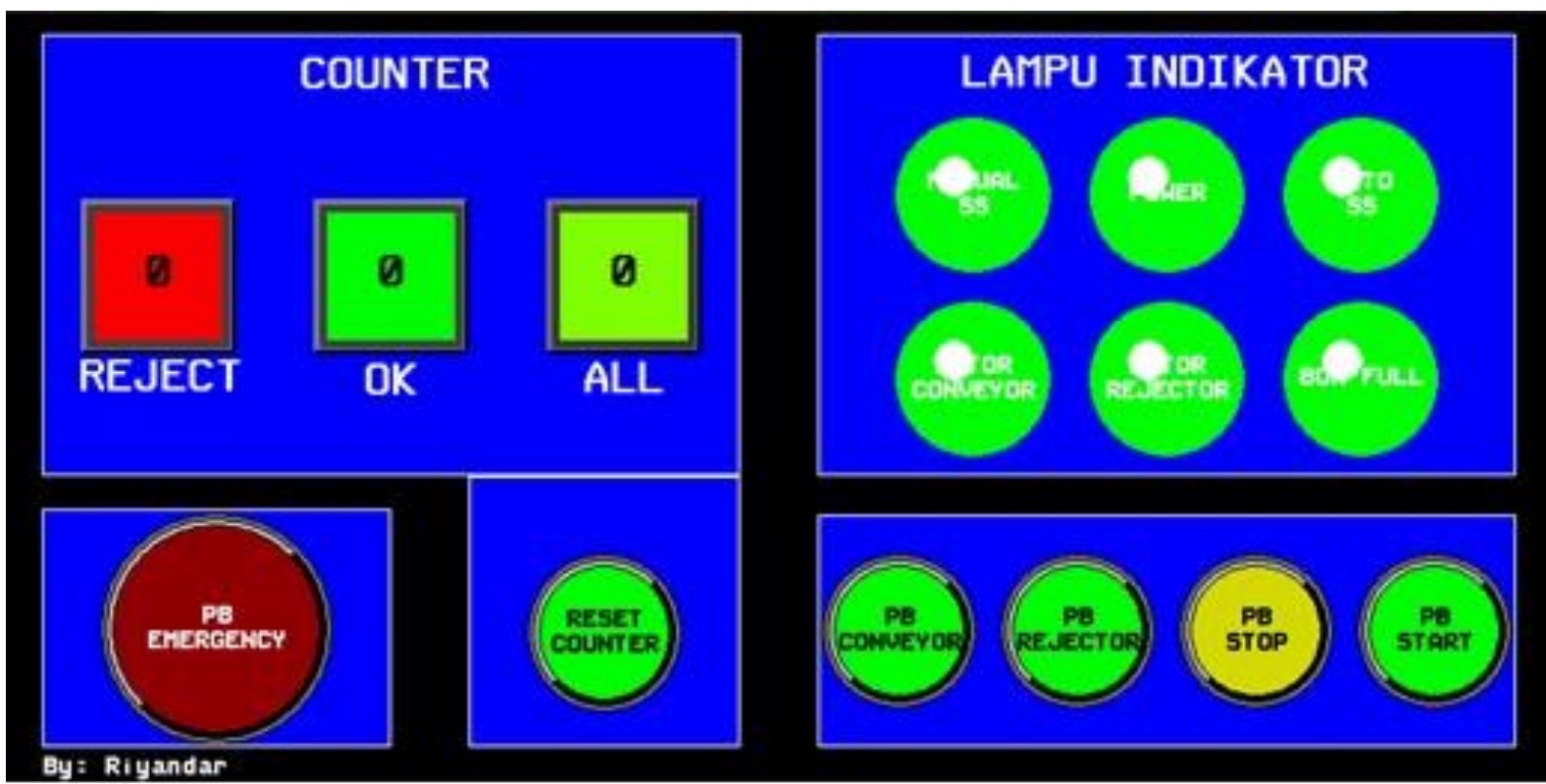

Gambar 8. Tampilan pada layar $H M I$

Berdasarkan Gambar 8 ditunjukkan, bahwa panel kondisi tutup botol pada miniatur konveyor, (ii) empat pengoperasian pada layar HMI, meliputi (i) push button push button warna hijau, berfungsi sebagai tombol start, untuk emergency stop berfungsi sebagai pemutus sistem reset counter, dan manual mode untuk mesin konveyor dan pengaman saat dilakukan pengecekan dan perbaikan dan motor wiper, (iii) satu push button warna kuning untuk pencegahan terjadi kecelakaan dan kerusakan part sebagai tombol stop, dan (iv) enam lampu indikator pada simulator rejection system untuk pengamatan berfungsi sebagai lampu power, manual selector switch,

DOI: https://doi.org/10.29207/resti.v5i6.3641

Lisensi: Creative Commons Attribution 4.0 International (CC BY 4.0) 
auto selector switch, motor konveyor, motor lengan berubah "ON" kembali dan botol dengan tutup "OK" rejector, kotak penampungan botol kondisi penuh, dan sampai masuk ke dalam boks penampungan, ketika boks

(v) counter untuk all botol, rejected, dan "OK".

@ Pengamatan terhadap pembacaan sensor-sensor yang terpasang pada prototipe dengan bantuan $H M I$

Pengamatan terhadap pembacaan sensor-sensor pada saat pengoperasian dapat diamati dari cara operasi simulator berbantuan HMI, yaitu, a) step awal pengoperasian simulator, berupa (i) kepastian keberadaan sumber tegangan $220 \mathrm{Vac}$ sudah siap, (ii) $M C B$ dalam posisi "ON", (iii) dipastikan sistem PLC dan $H M I$ dalam posisi "RUN", b) untuk pengoperasian simulator pada auto mode dilakukan dengan pemindahan posisi selector switch dua posisi yang berada di tengah panel kontrol dan lampu indikator auto selector switch pada layar HMI. Pengoperasian simulator dengan auto mode, diawali dengan step pertama posisi selector sudah pada posisi auto, lampu indikator auto dan lampu power pada layar HMI berwarna kuning penanda dalam kondisi "ON", proximity sensor \#1 untuk deteksi keberadaan botol pada miniatur mesin konveyor, maka motor konveyor menjadi "ON".

Sesaat kondisi tutup botol terdeteksi oleh proximity sensor \#1, motor konveyor dalam waktu 2 mili detik "OFF", maka motor wiper kondisi "ON" untuk berputar
ke arah kiri, kemudian counter pada layar HMI "ON", meliputi (i) all botol "ON" setalah terdeteksi oleh proximity sensor \#2, (ii) rejection "ON" setelah terdeteksi oleh proximity sensor \#3, (iii) keadan "OK" kondisi "ON" setelah counter all botol oleh proximity sensor \#2 dan rejection oleh proximity sensor \#3 beroperasi, maka ketika lengan rejector terdeteksi oleh proximity sensor \#4 lengan rejector, motor konveyor penampungan botol dengan status "OK" kondisi penuh terdeteksi oleh proximity sensor \#5 lampu indikator pada layar $H M I$ berubah berwarna dari hijau menjadi merah, motor konveyor berhenti ("OFF"), setelah keadaan "penuh" pada tempat penampungan tidak terdeteksi oleh proximity sensor \#5, maka motor konveyor beroperasi ("ON") kembali.

Prinsip operasi dengan manual model, cukup dilakukan dengan pemindahan selector switch ke posisi manual dan lampu indikator power, manual selector switch pada layar $H M I$ berubah menjadi warna kuning, tombol pada layar HMI push button untuk konveyor ditekan untuk motor konveyor kondisi "ON", tombol push button untuk motor wiper ditekan untuk kondisi "ON". Kondisi darurat, ditekan tombol emergency stop, maka sistem dalam kondisi "OFF". Berdasarkan prinsip operasi simulator, diamati untuk sensor-sensor terpasang pada simulator, "apakah sudah berfungsi seperti yang sudah diprogramkan ke dalam PLC?". Posisi ketika botolbotol dengan kondisi tutup "OK" terdeteksi oleh proximity sensor \#5, maka motor konveyor berhenti beroperasi ("OFF") dan lampu indikator untuk keadaan boks penampungan pada layar HMI berwarna merah, boks dirancang hanya untuk kondisi daya tampung tiga buah botol dengan kondisi tutup "OK”.

Tampilan counter untuk tutup botol dengan status rejected, "OK", all botol, dan lampu indikator untuk boks "penuh" pada layar $H M I$, seperti ditunjukkan pada Gambar 9.
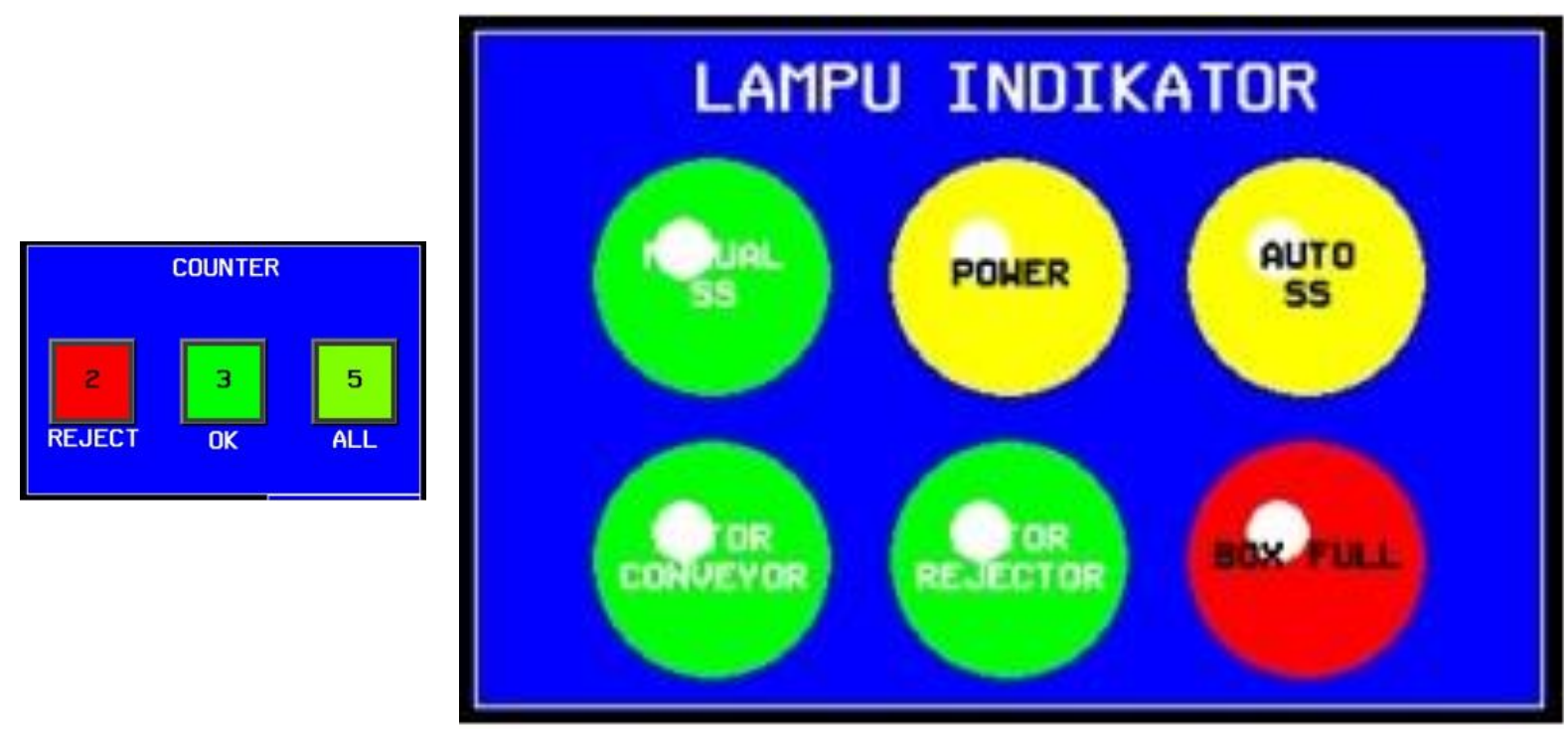

Gambar 9. Tampilan counter untuk tutup botol dengan status rejected, "OK", all botol, dan lampu indikator untuk boks "penuh" pada layar $H M I$

DOI: https://doi.org/10.29207/resti.v5i6.3641

Lisensi: Creative Commons Attribution 4.0 International (CC BY 4.0) 
Berdasarkan Gambar 9 dapat dijelaskan, bahwa (i) dari total lima botol terdapat dua botol dengan tutup rejected dan tiga botol dengan tutup "OK", (ii) lampu indikator boks kondisi "penuh dengan botol" pada layar HMI, semula berwarna hijau berubah menjadi warna merah, hal itu sebagai penanda boks kondisi penuh dan sistem beroperasi pada auto mode ditandai dengan lampu indikator power dan auto selector switch berwarna kuning. Lampu indikator untuk boks kondisi "penuh" pada layar $H M I$ berwarna merah, saat terdapat tiga botol dengan kondisi tutup botol "OK”.

@ Pengamatan dan pengukuran waktu proses putaran miniatur lengan rejector berbantuan sistem motor wiper

Pengukuran waktu proses perputaran lengan rejector berbantuan sistem motor wiper, merupakan salah satu tolok ukur suatu simulator saat beroperasi secara normal dan sesuai dengan perencanaan. Pengamatan dan pengukuran waktu proses lengan rejector terhadap boto pada miniatur konveyor dilakukan sebanyak tiga puluh detik.

kali. Hasil pengukuran untuk waktu operasi lengan rejector, baik secara manual (manual mode) maupun otomatis (auto mode), berupa waktu rata-rata. Pengamatan dan pengukuran waktu proses operasi lengan rejector, seperti ditunjukkan pada Tabel 3.
Tabel 3. Pengamatan dan pengukuran waktu proses operasi lengan rejector

\begin{tabular}{lccccc}
\hline ke- & $\begin{array}{c}\text { Manual } \\
\text { Mode } \\
\text { (detik) }\end{array}$ & $\begin{array}{c}\text { Auto } \\
\text { Mode } \\
\text { (detik) }\end{array}$ & ke- & $\begin{array}{c}\text { Manual } \\
\text { Mode } \\
\text { (detik) }\end{array}$ & $\begin{array}{c}\text { Auto } \\
\text { Mode } \\
\text { (detik) }\end{array}$ \\
\hline 1 & $00: 01: 30$ & $00: 01: 30$ & 16 & $00: 01: 25$ & $00: 01: 25$ \\
2 & $00: 01: 24$ & $00: 01: 28$ & 17 & $00: 01: 28$ & $00: 01: 28$ \\
3 & $00: 01: 26$ & $00: 01: 23$ & 18 & $00: 01: 27$ & $00: 01: 23$ \\
4 & $00: 01: 23$ & $00: 01: 23$ & 19 & $00: 01: 26$ & $00: 01: 23$ \\
5 & $00: 01: 24$ & $00: 01: 29$ & 20 & $00: 01: 26$ & $00: 01: 23$ \\
6 & $00: 01: 26$ & $00: 01: 26$ & 21 & $00: 01: 24$ & $00: 01: 23$ \\
7 & $00: 01: 26$ & $00: 01: 28$ & 22 & $00: 01: 24$ & $00: 01: 23$ \\
8 & $00: 01: 25$ & $00: 01: 25$ & 23 & $00: 01: 28$ & $00: 01: 23$ \\
9 & $00: 01: 22$ & $00: 01: 25$ & 24 & $00: 01: 23$ & $00: 01: 25$ \\
10 & $00: 01: 28$ & $00: 01: 28$ & 25 & $00: 01: 27$ & $00: 01: 25$ \\
11 & $00: 01: 28$ & $00: 01: 28$ & 26 & $00: 01: 26$ & $00: 01: 28$ \\
12 & $00: 01: 25$ & $00: 01: 23$ & 27 & $00: 01: 25$ & $00: 01: 23$ \\
13 & $00: 01: 28$ & $00: 01: 23$ & 28 & $00: 01: 25$ & $00: 01: 27$ \\
14 & $00: 01: 25$ & $00: 01: 23$ & 29 & $00: 01: 23$ & $00: 01: 23$ \\
15 & $00: 01: 23$ & $00: 01: 28$ & 30 & $00: 01: 23$ & $00: 01: 25$ \\
\hline \multicolumn{6}{l}{ Rata-rata: 00:01:25 detik(manual);00:01:25 detik (auto) } \\
\hline \multicolumn{6}{c}{}
\end{tabular}

Berdasarkan Tabel 3 ditunjukkan, bahwa waktu rata-rata operasi lengan rejector selama satu menit dua puluh lima Pengukuran terhadap botol dengan kondisi tutup rejected, seperti ditunjukknan pada Gambar 10.

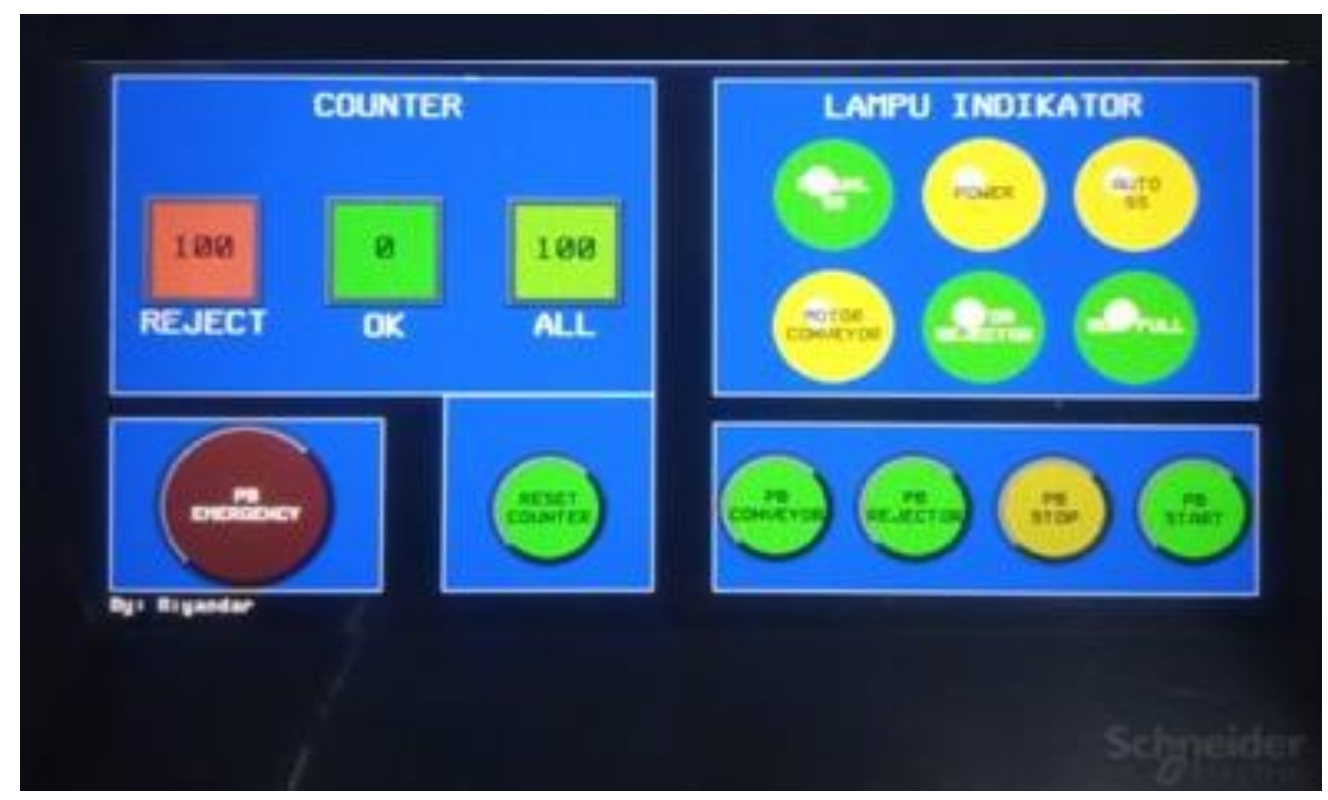

Gambar 10 Pengukuran terhadap botol dengan kondisi tutup rejected

Berdasarkan Gambar 10 ditunjukkan, bahwa setelah 4. Kesimpulan dilakukan pengukuran terhadap kondisi botol dengan tutup rejected, karena kerapatan pemasangan tutup botol lebih dari 1 milimeter terhadap seratus botol, terdeteksi oleh proximity sensor ke \#3 botol rejected sebanyak jumlah botol terdeteksi, sehingga diperoleh keakuratan rejection system untuk pengamatan kondisi tutup botol sebesar $100 \%$.

Berpedoman kepada hasil dan pembahasan, maka dapat ditarik kesimpulan sesuai sasaran penelitian. Fungsionalisasi bentuk fisis simulator rejection system pada miniatur mesin konveyor, dipabrikasi dan dirakit kembali melalui penggantian motor stepper dengan motor wiper sebagai penggerak lengan rejector dan penempatan sejumlah sensor pada konveyor, sehingga 
dilakukan tahapan lanjutan pengintegrasian seluruh komponen dan pengawatan pada sistem PLC dan HMI. Pemrograman untuk sistem tertanam pada simulator dilakukan dengan lima tahapan utama, yaitu (i) penyediaan software untuk PLC dan HMI, (ii) pemrograman terhadap $P L C$ berbasis ladder diagram, (iii) proses compiling dan uploading program dari $P C$ ke dalam $P L C$, (iv) konfigurasi $P L C$ dan $H M I$ via ethernet, dan (v) proses compiling dan uploading program dari $P C$ ke dalam HMI. Kinerja simulator rejection system untuk pengamatan kondisi tutup botol melalui $H M I$ diamati saat (i) sinkronisasi antara prototipe sistem dan kontrol $P L C$ berbantuan $H M I$, (ii) pembacaan sensor-sensor terpasang pada prototipe, dan (iii) proses putaran miniatur lengan rejector berbantuan sistem motor wiper. Secara keseluruhan, simulator rejection system berbasis $P L C$ dan berbantuan $H M I$ pada miniatur mesin konveyor dengan sensor proximity dapat dijadikan acuan untuk proses simulasi terhadap implementasi sistem rejection, karena keakuratan untuk pengamatan sebesar seratus persen.

Gambaran pengembangan ke depan terkait dengan penelitian ini, yaitu sistem berbentuk simulator untuk pengamatan terhadap kesempurnaan pemasangan tutup botol ini dapat dikembangkan dan diintegrasikan ke sistem pada fase-fase proses sebelumnya, seperti pengisian cairan ke dalam botol dan pemasangan tutup botol, maupun fase-fase setelah rejection system ini, sehingga dapat diperoleh sebuah sistem terintegratif dan user friendly berbasis PLC dan $H M I$ untuk sejumlah keperluan berbentuk simulator.

\section{Daftar Rujukan}

[1] M. Wildan, A. Goeritno, dan J. Irawan. (2021, April). Embedded Device Berbasis PLC pada Miniatur Konveyor untuk Pengoperasian Simulator Rejection System. Jurnal RESTI (Rekayasa Sistem dan Teknologi Informasi). 5(2), 301-311. Tersedia di: https://doi.org/10.29207/resti.v5i2.2994

[2] OMRON, The CP1E Programmable Controller: Economical, Easy to Use, and Efficient. Tokyo, Japan: Omron, pp. 1-48, 2013.

[3] Schneider Electric. (2020, November). Modicon M221 Logic Controller: User Guide. Scheider Electric. City of Clute, TX. [Online]. Avalaible: https://download.schneiderelectric.com/files?p_enDocType $=U$ ser+guide\&p_File_Name $=\mathrm{E}$ IO0000000976.02.pdf\&p_Doc_Ref=EIO0000000976

[4] Schneider Electric. (2020, September). Easy Harmony GXU User Manual. Scheider Electric. City of Clute, TX. [Online]. Avalaible: https://download.schneiderelectric.com/files?p_enDocType $=U$ ser+guide \&p_File_Name $=\mathrm{E}$ IO0000002073.03.pdf\&p_Doc_Ref=EIO0000002073

[5] T.A. Kinney. (2015, December 23). Proximity Sensors Compared: Inductive, Capacitive, Photoelectric, and Ultrasonic. Machine Design website. [Online]. Available: https://www.machinedesign.com/automationiiot/sensors/article/21831577/proximity-sensors-comparedinductive-capacitive-photoelectric-and-ultrasonic

[6] I. Morishita, and M. Okumura, "Automated Visual Inspection Systems for Indutrial Applications," Measurement, vol. 1, no. 2, pp. 59-67, 1983.

[7] S.P. Kumar, and H.V. Ramakrishna, "Automated Bottle Cap Inspection Using Machine Vision System," International
Journal of Innovative Research in Technology, vol. 2, no. 2, pp. 131-136, 2015.

[8] S. Sridevi, P. Karthikeyan, C.A. Prakash, A. Jaganathan, and A. Mani, "Bottle Cap Inspection Based on Machine Vision," International Journal of Engineering Research \& Technology (IJERT), vol. 4, no. 26, pp. 1-4, 2016.

[9] Prismanto, D.T. Nugroho, Y. Ramadhani, dan T. Herdantyo, "Penerapan Programmable Logic Controller Human Machine Interface Untuk Monitoring Objek pada Konveyor," Prosiding Pengembangan Sumber Daya Perdesaan dan Kearifan Lokal Berkelanjutan, 2018, [tema: 4, energy baru dan terbarukan]

[10] W. Bolton, Programmable Logic Controllers, 4th ed. Burlington, MA: Elsevier Newnes, pp. 1-14, 2006.

[11] A. Goeritno, dan S. Pratama, "Rancang-Bangun Prototipe Sistem Kontrol Berbasis Programmable Logic Controller untuk Pengoperasian Miniatur Penyortiran Material. Jurnal Rekayasa Elektrika, vol. 16, no. 3, hlm. 198-206, Desember 2020. http://dx.doi.org/10.17529/jre.v16i3.14905

[12] S. Tirta, dan A. Goeritno. (2020, Desember). Simulator Berbasis PLC untuk Pengaturan Lalu-lintas Jalan Raya pada Perlintasan Jalur Kapal. Jurnal RESTI. [Online]. 4(6), hlm. 1007-1016. Tersedia: https://doi.org/10.29207/resti.v4i6.2668

[13] H. Carlsson, B. Svensson, F. Danielsson, and B. Lennartson, "Methods for Reliable Simulation-Based PLC Code Verification," in IEEE Transactions on Industrial Informatics, vol. 8, no. 2, pp. 267-278, May 2012, http://dx.doi: 10.1109/TII.2011.2182653

[14] S.Y. Dimpudus, V.C. Poekoel, dan P.D.K. Manembu. (2015). Sistem Pengepakan Botol Minuman Kemasan Berbasis Programmable Logic Controller. E-Journal Teknik Elektro dan Komputer. [Online]. 4(7), hlm. 65-72. Tersedia: https://ejournal.unsrat.ac.id/index.php/elekdankom/article/view/ $10717 / 10305$

[15] R. Pawar, and N.R. Bhasme. (2016, June). Application of PLC's for Automation of Processes in Industries. Int. Journal of Engineering Research and Applications. [Online]. 6(6), pp. 5359. Available: https://www.ijera.com/papers/Vol6_issue6/Part\%20 $\% 203 /$ 0606035359.pdf

[16] E.R. Alphonsus, and M.O. Abdullah. (2016, July). A review on the applications of programmable logic controllers (PLCs). Renewable and Sustainable Energy Reviews. [Online]. 60(C), pp. 1185-1205. https://doi.org/10.1016/j.rser.2016.01.025

17] M.S. Saleh, K.G. Mohammed, Z.S. Al-sagar, and A.Z. Sameen. "Design and Implementation of PLC-Based Monitoring and Sequence Controller System," Journal of Advanced Research in Dynamical and Control Systems, vol 10, no. 02 special issue, pp. 2281-2289, 2018.

18] R. Langmann, and M. Stiller. (2019). The PLC as a Smart Service in Industry 4.0 Production Systems. Applied Science. [Online]. (3815), 1-20. Available: https://res.mdpi.com/d_attachment/applsci/applsci-0903815/article_deploy/applsci-09-03815-v2.pdf

[19] A. Goeritno, dan Y. Herutama, "Sistem Elektronis Berbantuan PC untuk Pemantauan Kondisi Pasokan Daya Listrik," Jurnal Rekayasa Elektrika, vol. 14, no. 2, hlm. 96-104, 2018. http://dx.doi.org/10.17529/jre.v14i2.10904

[20] A. Goeritno, dan I. Mustofa. (2017, Juni). Minimum System Berbasis Mikrokontroler ATmega32 untuk Pemantauan dan Tampilan Kondisi Instalasi Kelistrikan Otobis, Jurnal Ilmiah SETRUM. [Online]. 6(1), hlm.55-67. Tersedia: https://jurnal.untirta.ac.id/index.php/jis/article/view/1721/2122

[21] A. Goeritno, S.F. Ginting, dan R. Yatim. (2017, Juli 25). Pengoperasian Beban Listrik Fase Tunggal Terkendali melalui Minimum System Berbasis Mikrokontroler dan Sensor Voice Recognition (VR). SNATIF ke-4 tahun 2017 FT UMK. [Online]. Tersedia: https://jurnal.umk.ac.id/index.php/SNA/article/view/1244/862

22] A. Goeritno, Sopyandi, dan R. Yatim. (2017, Juli 25). Bebanbeban Listrik Terkontrol melalui Minimum System Berbasis

DOI: https://doi.org/10.29207/resti.v5i6.3641

Lisensi: Creative Commons Attribution 4.0 International (CC BY 4.0) 
Payload Data Handling Berbantuan Mikrokontroler. SNATIF ke4 tahun 2017 FT UMK. [Online]. Tersedia: https://jurnal.umk.ac.id/index.php/SNA/article/view/1270/882

[23] M.Y. Afandi, A. Goeritno, dan R. Yatim (2017, Juli 25). Minimum System Berbasis Mikrokontroler ATmega32 Berbantuan Sensor Passive Infrared Receiver dan Fingerprint Untuk Sistem Pengamanan Kendaraan Bermotor Roda Empat atau Lebih. SNATIF ke-4 tahun 2017 FT UMK. [Online]. Tersedia: https://jurnal.umk.ac.id/index.php/SNA/article/view/1264/879

[24] M.T. Sholehati, dan A. Goeritno, "Sistem Minimum Berbasis Mikrokontroler ATmega2560 sebagai Sistem Pengaman pada Analogi Lemari Penyimpanan Brankas," Jurnal Rekayasa Elektrika, vol. 14, no. 3, hlm. 158-166, Desember 2018. http://dx.doi.org/10.17529/jre.v14i3.11649

[25] A. Goeritno, dan M.Y. Afandi, "Modul Elektronika Berbasis Mikrokontroler sebagai Sistem Pengaman pada Mobil Terintegrasi dengan Engine Immobilizer," Jurnal Rekayasa Elektrika, vol. 15, no. 2, hlm. 75-84, Agustus 2019. http://dx.doi.org/10.17529/jre.v15i2.12872

[26] A.E.K. Pramuko, S. Asura, A. Goeritno, dan Ritzkal. (2017, Feb. 4). Pengkondisian Suhu Ruangan Berbantuan Sensor LM35 dan Passive Infrared (PIR) Berbasis Mikrokontroler Arduino Uno R3. Seminar Nasional Inovasi dan Aplikasi di Industri (SENIATI) 2017 ITN Malang. [Online]. Tersedia: http://ejournal.itn.ac.id/index.php/seniati/article/view/766

[27] A. Goeritno, S. Asyura, Ritzkal, A.E.K. Pramuko, B.A. Prakoso, "Minimum System Berbasis Mikrokontroler Berbantuan Sensor Passive Infrared (PIR) dan Sensor Suhu LM35 Untuk Pengkondisian Suhu pada Analogi Ruangan,” di SNMI-VIII UBL, Jakarta Barat, JK, 22 April 2017, hlm. (ICT) 281-293.

[28] F. Hendrian, Ritzkal, dan A. Goeritno, "Penggunaan Protokol Internet untuk Sistem Pemantauan pada Analogi Instalasi Listrik Fase-3 Berbantuan Mikrokontroler Arduino UNO R3 Terkendali melalui Smartphone Berbasis Android," di Prosiding SNRT ke-2 FST-UPH, Tangerang, BT, 17-18 Mei 2017, hlm. (II) 103-110.

[29] A. Goeritno, F. Hendrian, dan Ritzkal. (2017, Juli 25). "Lampu Pijar pada Analogi Instalasi Listrik Fase-Tiga Terkendali melalu[37] Smartphone Berbasis Android Terhubung Internet Berbantuan Mikrokontroler," di Prosiding SNATIF ke-4, Fakultas Teknik Universitas Muria Kudus. [Online]. Tersedia: http://jurnal.umk.ac.id/index.php/SNA/article/view/1243/861

[30] I. Setyawibawa, dan A. Goeritno. (2019, April). Communication Interface Adapter Berbasis Mikrokontroler Arduino Terkendali
Sinyal Dual Tone Multi Frequency, Jurnal ELKHA (Jurnal Teknik Elektro). [Online]. 11(1), hlm.19-26, 2019. http://dx.doi.org/10.26418/elkha.v11i1.30374

[31] A. Goeritno, F. Hendrian, dan Ritzkal. (2019, Desember). Pengendalian Lampu Pijar pada Analogi Instalasi Listrik FaseTiga melalui Smartphone Berbasis Android Berbantuan Jaringan Wi-Fi. Jurnal Ilmiah SETRUM. [Online]. 8(2), hlm. 274-286. Tersedia: https://jurnal.untirta.ac.id/index.php/jis/article/view/6977/pdf_6

[32] A.F. Nasyarudin, Ritzkal, dan A. Goeritno. (2020, October). Prototipe Perangkat untuk Pemantauan dan Pengendalian Berbasis Web Diiintegrasikan ke Smarthome System, Indonesian Journal of Electronics and Instrumentations Systems (IJEIS). [Online]. 10(2), $\quad$ hlm. https://doi.org/10.22146/ijeis.58316

[33] L. Hardian, dan A. Goeritno. (2021, Februari). Pabrikasi Unit Kontrol Berbasis Web pada Smarthome System untuk Pengoperasian Pintu Gerbang. Jurnal RESTI (Rekayasa Sistem dan Teknologi Informasi). [Online]. 5(1), hlm. 163-173. Tersedia: https://doi.org/10.29207/resti.v5i1.2879

[34] S. Suhendri, dan A. Goeritno, "Pemantauan Energi Listrik pada Satu kWH-meter Fase Tunggal untuk Empat Kelompok Beban Berbasis Metode Payload Data Handling," Jurnal Rekayasa Elektrika, vol. 14, no. 3, hlm. 189-197, Desember 2018. http://dx.doi.org/10.17529/jre.v14i3.11952

[35] D. Suhartono, dan A. Goeritno. (2019, April). Prototipe Sistem Berbasis Mikrokontroler untuk Pengkondisian Suhu pada Analogi Panel dengan Analogi Sistem Air Conditioning, Jurnal EECCIS (Electrics, Electronics, Communications, Controls, Informatics, Systems). [Online]. 13(1), hlm. 22-30. Tersedia: https://jurnaleeccis.ub.ac.id/index.php/eeccis/article/download/5 $54 / 345$

[36] D. Darussalam, dan A. Goeritno. (2021, April). Pemanfaatan RFID, Loadcell, dan Sensor Infrared Untuk Miniatur Penukaran Botol Plastik Bekas, Jurnal RESTI. [Online]. 5(2), hlm. 281-291. Tersedia: https://doi.org/10.29207/resti.v5i2.3048

] F.G. Airlangga, A. Triwiyatno, dan Sumardi. (2017, Maret). Perancangan Sistem Automasi pada Pengemasan Susu Dalam Botol dengan Programmable Logic Controller (PLC) Omron CP1E terhadap Purwarupa Filling Bottle and Capping Machine, Transient. [Online]. 6(1), hlm. 103-109. Tersedia: https://ejournal3.undip.ac.id/index.php/transient/article/download $/ 17069 / 16354$

DOI: https://doi.org/10.29207/resti.v5i6.3641 